\title{
Water needs of Sambucus nigra L. grown in the reclaimed areas in Poland
}

\author{
Barbara Lidia Jagosz ${ }^{1 *}$, Stanislaw Rolbiecki², Anna Figas ${ }^{3}$, Wieslaw Ptach, \\ Roman Rolbiecki ${ }^{2}$, Piotr Stachowski ${ }^{5}$, Wiestawa Kasperska-Wolowicz, \\ Vilda Grybauskiene ${ }^{7}$, Andrzej Klimek ${ }^{8}$, Krzysztof Dobosz ${ }^{9}$
}

\begin{abstract}
${ }^{1}$ Institute of Plant Biology and Biotechnology, University of Agriculture in Krakow, Poland ${ }^{2}$ Department of Agrometeorology, Plant Irrigation and Horticulture, University of Science and Technology in Bydgoszcz, Poland ${ }^{3}$ Department of Plant Genetics, Physiology and Biotechnology, University of Science and Technology in Bydgoszcz, Poland ${ }^{4}$ Faculty of Civil and Environmental Engineering, Warsaw University of Life Sciences, Poland ${ }^{5}$ Institute of Land Improvement, Environmental Development and Geodesy Faculty of Environmental Engineering and Spatial Management, Poznań University of Life Sciences, Poland ${ }^{6}$ Institute of Technology and Life Sciences, Kuyavian-Pomeranian Research Centre, Bydgoszcz, Poland

${ }^{7}$ Faculty of Water and Land Management, Aleksandras Stulginskis University in Kaunas, Lithuania ${ }^{8}$ Department of Zoology and Landscaping, University of Science and Technology, Bydgoszcz, Poland

${ }^{9}$ Faculty of Medical Sciences, University of Economy, Bydgoszcz, Poland
\end{abstract}

\begin{abstract}
The goal of this study was to assess the water needs of elderberry. The investigation included elderberry plants that had been planted in land reclamation areas more than three years earlier. The water needs were evaluated for 5 agro-climatic regions of Poland. The calculations were based on the observation of meteorological conditions in the years 1981-2010 for the period from June 1 to July 31. To determine the water needs, the plant coefficient method was applied. The Blaney-Criddle formula, which was modified for Polish conditions by Żakowicz (2010), was used to calculate the reference evapotranspiration. The plant coefficients of elderberry, adapted to the reference evapotranspiration, were adjusted to Żakowicz's method. The rainfall deficit with the probability of occurrence: $\mathrm{N}_{50 \%}, \mathrm{~N}_{25 \%}$ and $\mathrm{N}_{10 \%}$, was assessed in accordance with Ostromęcki's method. The highest water needs of elderberry occurred in central-north-west $(264 \mathrm{~mm})$ and central-east $(262 \mathrm{~mm})$ Poland, while the lowest $(244 \mathrm{~mm})$ in the south-east region. In June, the highest total monthly water needs $(119 \mathrm{~mm})$ were noted for south-west Poland, whereas the lowest $(107 \mathrm{~mm}$ ) for the south-east region. In June and July, except for the central-north-west region, an upward time trend of water needs was noted throughout Poland. In June and July, the highest value $\left(135 \mathrm{~mm}\right.$ ) of rainfall deficit $\mathrm{N}_{50 \%}$ and $\mathrm{N}_{25 \%}$ was estimated for the central-north-west region, while the highest rainfall deficit $\mathrm{N}_{10 \%}(269 \mathrm{~mm})$ for central-east Poland. The results of the presented research find application in the planning of irrigation treatments for elderberry in Poland.
\end{abstract}

Key word s: crop evapotranspiration, irrigation, plant coefficient, rainfall deficit, reference evapotranspiration

\section{INTRODUCTION}

Elderberry (Sambucus nigra L.) (Adoxaceae family) is a popular species used as an ornamental as well as medicinal plant (Podbielkowski, 1989). Sambucus nigra L. plants grow in very diverse habitats. Elderberry trees can be found both in cities and rural areas. This species occurs in 
forests and home gardens, and also cemeteries. Elderberry plants inhabit balks, scrubs, ground and railway embankments. Sambucus nigra L. has low soil requirements, but it grows best on moist and humus soils (Seneta, 1991). Several elderberry cultivars, including Aurea, Aureomarginata, Black Beauty and Laciniata, have unique decorative qualities, such as the different shape and colour of the leaves and flowers, so they are eagerly planted in gardens and parks (Kawecki et al., 2008). Both wild and cultivated elderberry plants are used not only as ornamental and medicinal plants, but also in crafts and games, and are also a source of food for humans and animals. This species also finds use as windbreaks and for stabilizing river banks (Charlebois et al., 2010). The elderberry fruits belong to the so-called super fruits group; they are characterized by a high concentration of nutrients with proven high biological activities. Their health-promoting properties include, above all, antioxidant activity, protective effects in diseases of the cardiovascular system, as well as support in diabetes and obesity (Kołodziej and Drożdżal, 2011; Gramza-Michałowska and Sidor, 2015; Nurzyńska-Wierdak, 2016). The nectar and pollen of Sambucus nigra L. are also a rich source of food for adult syrphids, while Aphis sambuci aphids are eaten by syrphid larvae. In connection with the above, elderberry plants can also be used to attract these beneficial insects to near fields and orchards (Wojciechowicz-Żytko and Jankowska, 2016).

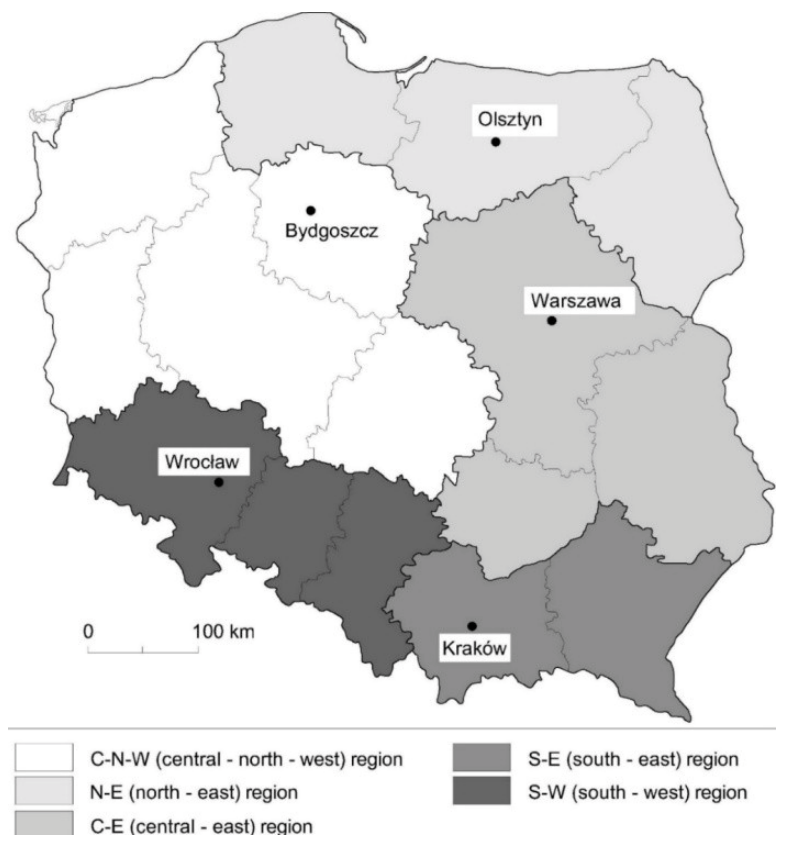

Figure 1. The agro-climatic regions of Poland included in the study (Labędzki et al., 2013)
High seedling rate of elderberry in parks or gardens depends largely on the soil water content, which can be replenished using properly designed and managed micro-irrigation systems (Żakowicz, 2010; Żakowicz and Hewelke, 2012). However, before performing the irrigation treatments, it is necessary to estimate the water needs of the plants introduced into a specific area.

The purpose of this investigation was to calculate the water needs of elderberry trees grown in land reclamation areas for more than three years after planting. The water needs were assessed for the period when the water needs of plants generally increase, i.e. from June 1 to July 31, over a thirty-year interval (1981-2010), in different regions of Poland. The current studies are a continuation of the investigation published by Rolbiecki et al. (2018), which analyzed the water needs of elderberry during the first three years after planting in the reclaimed areas.

\section{MATERIAL AND METHODS}

The elderberry (Sambucus nigra L.) water needs were calculated by the plant coefficient method. The plant coefficients for elderberry plants in the period three years or more after reclamation, which is the second stage of this process, were adapted to the reference evapotranspiration. The BlaneyCriddle formula, transformed for Polish conditions by Żakowicz (2010), was applied to determine the reference evapotranspiration. The water needs (Etp) of elderberry trees were assessed for the months when the water needs of plants usually increase, i.e. for the period between June 1 and July 31, and also separately for June, in the thirty-year interval from 1981 to 2010 . The calculations were carried out using data from 5 meteorological stations located in Olsztyn, Bydgoszcz, Warsaw, Wrocław and Kraków, which were representative of five agro-climatic regions of Poland, i.e. the north-east region $(\mathrm{N}-\mathrm{E})$, central-north-west region $(\mathrm{C}-\mathrm{N}-\mathrm{W})$, central-east region (C-E), south-west region (S-W) and the south-east region (S-E), respectively (Łabędzki et al., 2013) (Fig. 1).

The obtained results were statistically estimated by the average $(\mathrm{mm})$, median $(\mathrm{mm})$, maximal and minimal values $(\mathrm{mm})$, standard deviation $(\mathrm{mm})$, and also the variability coefficient (\%). Furthermore, calculations were made in order to determine possible trends in the changes of elderberrytree water needs in the five regions studied using linear regression analysis with the evaluation of determination coefficients and correlation 
coefficients. The rainfall deficit at the probability of occurrence $\left(\mathrm{N}_{50 \%}, \mathrm{~N}_{25 \%}\right.$ and $\left.\mathrm{N}_{10 \%}\right)$ was calculated in accordance with Ostromęcki's method (Żakowicz et al., 2009).

\section{RESULTS AND DISCUSSION}

The variability in elderberry-tree water needs in the period of two months, i.e. June and July, was relatively low in all the considered regions of Poland (Tab. 1). In June and July, the value of the variation coefficient of elderberry water needs ranged from $4.3 \%$ in the S-E region to $4.6 \%$ in the S-W region of Poland. In June, the variation coefficient of elderberry water needs was higher and varied between $4.5 \%$ in the N-E region and $5.3 \%$ in the S-W region of Poland.

Based on the presented calculations for the thirty-year period from 1981 to 2010, throughout Poland, i.e. in all the considered agro-climatic regions, a visible increase was observed in the water needs (Etp) of elderberry trees in the period from
June 1 to July 31 (Fig. 2). Except for the C-N-W region, the time trend of elderberry water needs was significant throughout Poland. The highest increase in elderberry-tree water needs (by $7.1 \mathrm{~mm}$ in each subsequent decade) was observed in the S-E region. On average, in the years 1981-2010, throughout Poland, the water needs of elderberry trees in the June-July period rose by $6.1 \mathrm{~mm}$ in each subsequent ten-year interval (decade). In the previous study published by Rolbiecki et al. (2018), the elderberry water needs throughout Poland during June and July, estimated for the first three years after planting in reclaimed areas (the first stage of reclamation), increased by $5.4 \mathrm{~mm}$ in each subsequent decade of the considered interval from 1981 to 2010. According to Rolbiecki et al. (2018), from June 1 to July 31 , in each decade of the thirty-year period, the increase in elderberry water needs ranged from $3.6 \mathrm{~mm}$ in the central-north-west region to $6.2 \mathrm{~mm}$ in the south-east region of Poland. The difference between the water needs of young elderberry plants

Table 1. Statistical characteristics of elderberry-tree water needs in June and July, and separately in June

\begin{tabular}{|c|c|c|c|}
\hline \multirow{2}{*}{ Parameter } & \multirow{2}{*}{ Region of Poland } & \multicolumn{2}{|c|}{ Water needs } \\
\hline & & June-July & June \\
\hline \multirow{5}{*}{ Minimum (mm) } & north-east (N-E) & 227.3 & 99.6 \\
\hline & central-north-west (C-N-W) & 241.0 & 105.4 \\
\hline & central-east $(\mathrm{C}-\mathrm{E})$ & 234.4 & 104.4 \\
\hline & south-west (S-W) & 223.4 & 107.0 \\
\hline & south-east (S-E) & 218.9 & 94.9 \\
\hline \multirow{5}{*}{ Maximum (mm) } & north-east (N-E) & 272.0 & 118.8 \\
\hline & central-north-west (C-N-W) & 292.0 & 126.5 \\
\hline & central-east $(\mathrm{C}-\mathrm{E})$ & 289.8 & 122.7 \\
\hline & south-west (S-W) & 275.5 & 131.5 \\
\hline & south-east (S-E) & 261.9 & 117.0 \\
\hline \multirow{5}{*}{ Median (mm) } & north-east (N-E) & 251.1 & 110.3 \\
\hline & entral-north-west (C-N-W) & 265.7 & 116.0 \\
\hline & central-east (C-E) & 261.3 & 115.1 \\
\hline & south-west (S-W) & 245.6 & 119.1 \\
\hline & south-east (S-E) & 244.4 & 107.1 \\
\hline \multirow{5}{*}{ Standard deviation (mm) } & north-east (N-E) & 11.0 & 4.9 \\
\hline & entral-north-west (C-N-W) & 12.0 & 5.4 \\
\hline & central-east (C-E) & 11.5 & 5.4 \\
\hline & south-west (S-W) & 11.4 & 6.3 \\
\hline & south-east (S-E) & 10.4 & 5.1 \\
\hline \multirow{5}{*}{ Variation coefficient $(\%)$} & north-east (N-E) & 4.4 & 4.5 \\
\hline & entral-north-west (C-N-W) & 4.5 & 4.7 \\
\hline & central-east (C-E) & 4.4 & 4.7 \\
\hline & south-west (S-W) & 4.6 & 5.3 \\
\hline & south-east (S-E) & 4.3 & 4.8 \\
\hline
\end{tabular}



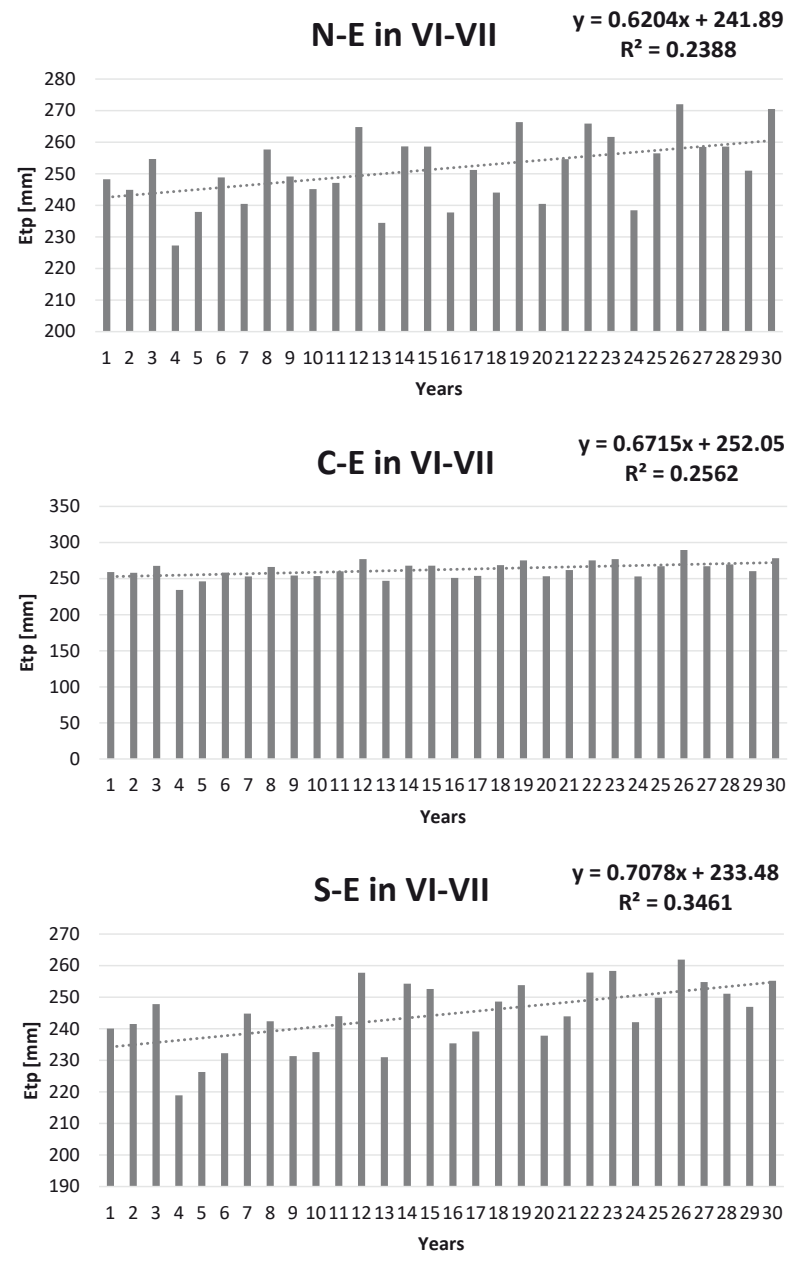
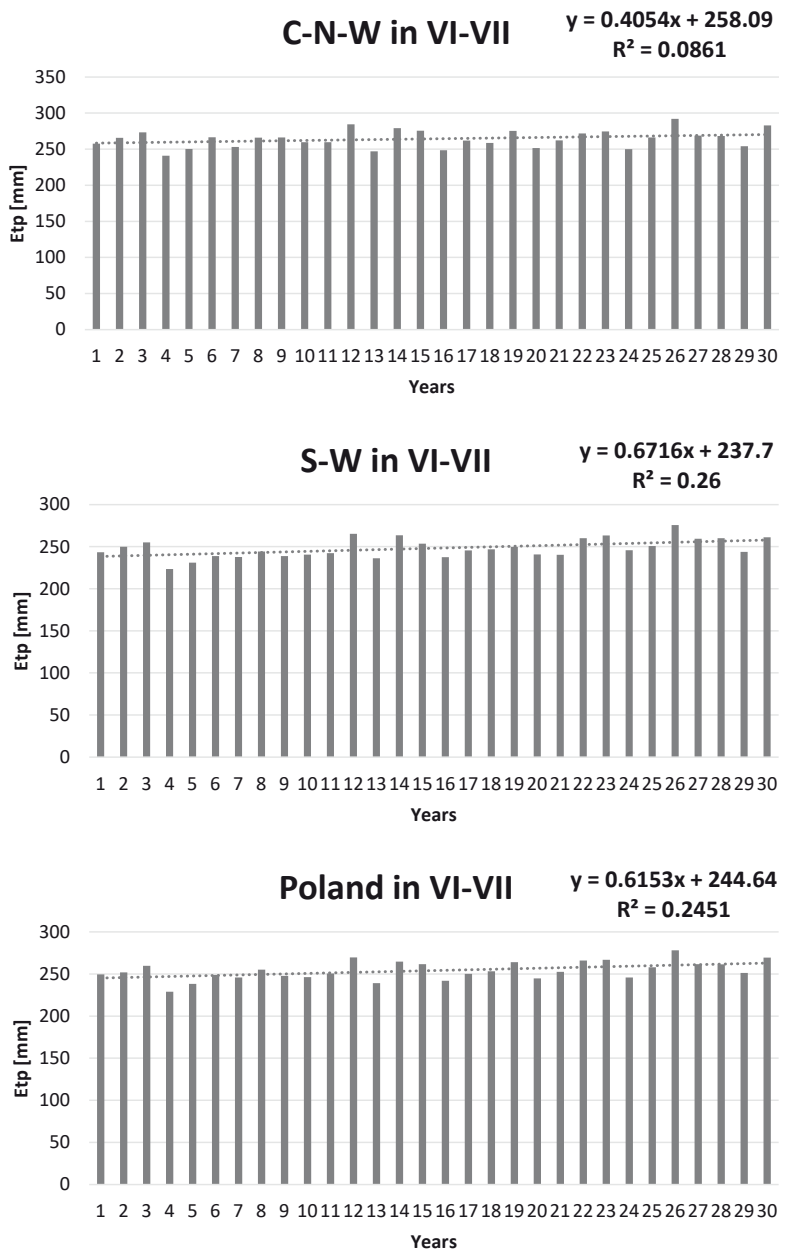

Figure 2. Time trend of elderberry-tree water needs (Etp) in June and July

considered by Rolbiecki et al. (2018) and the over three-year-old elderberry-trees studied presently, is the result of plant's age (Żakowicz, 2010).

On average, during the two months of June and July of the years between 1981 and 2010, the highest water needs of elderberry trees, grown for more than three years in the reclaimed areas, were estimated for the C-N-W (264 mm) and C-E $(262 \mathrm{~mm})$ regions, whereas the lowest water needs $(244 \mathrm{~mm})$ were calculated for the S-E region of
Poland (Fig. 3). In June, the highest total monthly water needs $(119 \mathrm{~mm})$ of elderberry trees were found in the $\mathrm{S}-\mathrm{W}$ region, while the lowest $(107 \mathrm{~mm})$ in the S-E region of Poland. According to Rolbiecki et al. (2018), in June and July, the highest water needs of elderberry plants in the first three years of growing after reclamation occurred in the $\mathrm{C}-\mathrm{N}-\mathrm{W}$ $(232 \mathrm{~mm})$ and C-E $(230 \mathrm{~mm})$ regions of Poland.

In June, in all the considered regions of Poland, a visible rise in the elderberry-tree water needs
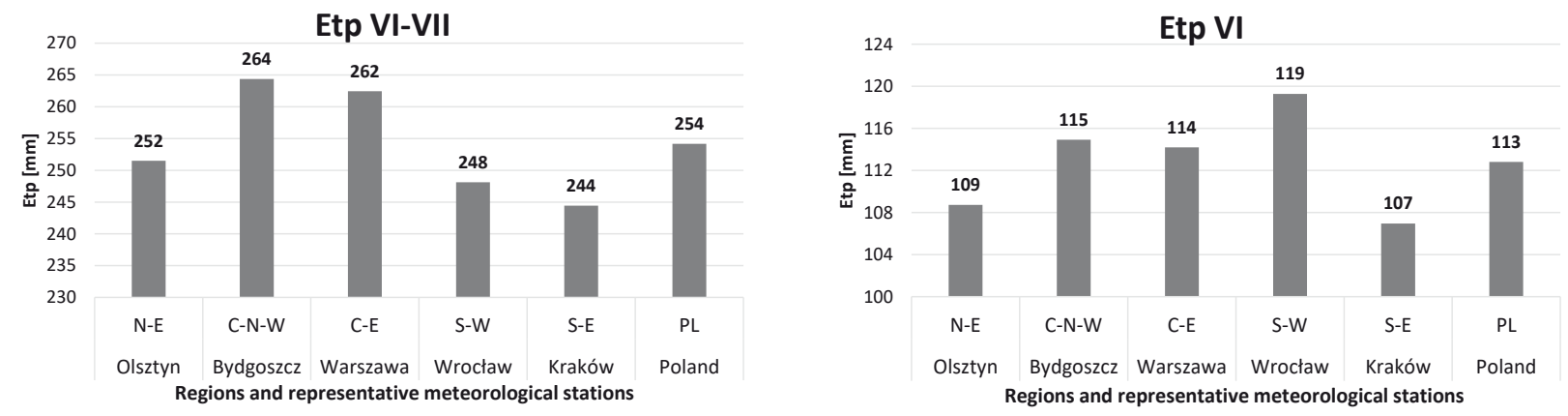

Figure 3. Water needs (Etp) of elderberry-trees in June and July, and separately in June 

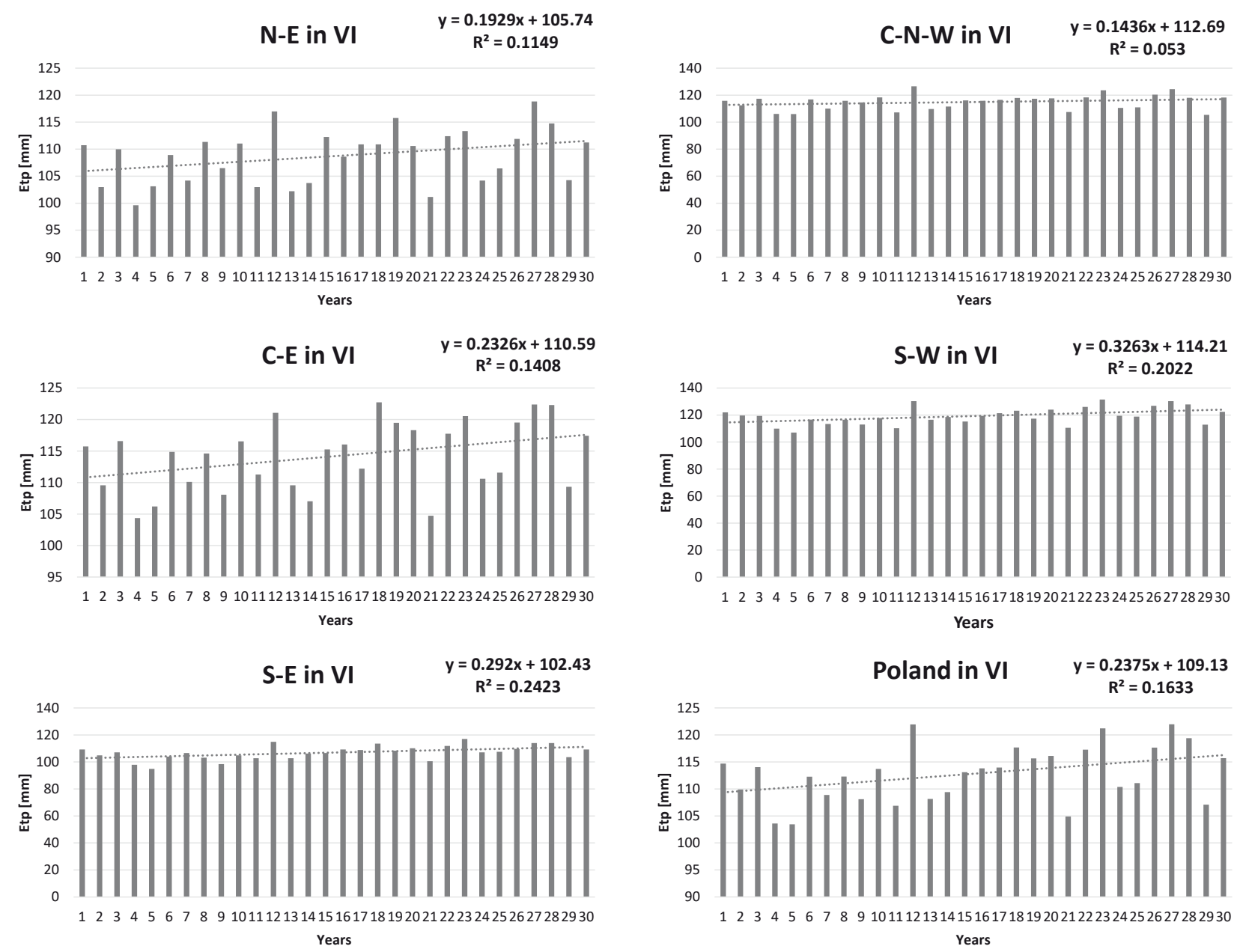

Figure 4. Time trend of elderberry-tree water needs (Etp) in June

was observed (Fig. 4). Moreover, throughout the country, except the $\mathrm{C}-\mathrm{N}-\mathrm{W}$ region, the time trend of elderberry water needs was statistically significant. In the years 1981-2010, in June, the water needs of elderberry trees increased the most (by $3.3 \mathrm{~mm}$ in every subsequent decade) in the $\mathrm{S}-\mathrm{W}$ region of Poland. An insignificant time trend of the elderberry-tree water needs (only $1.4 \mathrm{~mm}$ ) was noted in the C-N-W region. On average, in June of the years 1981-2010, throughout Poland, the water needs of elderberry trees rose by $2.4 \mathrm{~mm}$ in every subsequent ten-year interval.

In the months of June and July, the highest rainfall deficit $\mathrm{N}_{50 \%}(135 \mathrm{~mm})$ was noted in the C-N-W region of Poland (Tab. 2). In the June-July interval, the highest rainfall deficit $\mathrm{N}_{25 \%}$ occurred

Table 2. Rainfall deficit (mm) of elderberry trees

\begin{tabular}{lrrrrr}
\hline \multirow{2}{*}{$\begin{array}{l}\text { Rainfall deficit } \\
\text { probability of occurrence) }\end{array}$} & \multicolumn{5}{c}{ Region of Poland } \\
\cline { 2 - 6 } & $\mathrm{N}-\mathrm{E}$ & $\mathrm{C}-\mathrm{N}-\mathrm{W}$ & $\mathrm{C}-\mathrm{E}$ & $\mathrm{S}-\mathrm{W}$ & $\mathrm{S}-\mathrm{E}$ \\
\hline$n_{\mathrm{N}}$ & 101 & 135 & 113 & 99 & 69 \\
$\mathrm{~N}_{25 \%}$ & 195 & 213 & 195 & 155 & 135 \\
$\mathrm{~N}_{10 \%}$ & 237 & 262 & 269 & 225 & 178 \\
\hline $\mathrm{N}_{50 \%}$ & & & June-July & \\
$\mathrm{N}_{25 \%}$ & 32 & 64 & 42 & 50 & 20 \\
$\mathrm{~N}_{10 \%}$ & 71 & 79 & 67 & 68 & 32 \\
\hline
\end{tabular}

N-E - north-east; C-N-W - central-north-west; C-E - central-east; S-W - south-west; S-E - south-east 
in the N-E and C-E (195 mm), as well as in the $\mathrm{C}-\mathrm{N}-\mathrm{W}$ region of Poland $(213 \mathrm{~mm})$. The highest rainfall deficit $\mathrm{N}_{10 \%}$ was calculated for the N-E $(237 \mathrm{~mm})$ and C-E $(269 \mathrm{~mm})$ regions. In June and July, the rainfall deficits $\mathrm{N}_{25 \%}$ and $\mathrm{N}_{10 \%}$ in the S-W and S-E Poland were lower than in the N-E, C-N-W and $\mathrm{C}-\mathrm{E}$ regions of the country. At this point, it should be mentioned that the rainfall deficit $\mathrm{N}_{10 \%}$ value covers $90 \%$ of the water needs of elderberry trees estimated for June and July (Żakowicz et al., 2009). In June, the highest rainfall deficit values $\mathrm{N}_{50 \%}(64 \mathrm{~mm})$ and $\mathrm{N}_{25 \%}(79 \mathrm{~mm})$ were noted in $\mathrm{C}-\mathrm{N}-\mathrm{W}$ Poland. At the same time, the highest value of rainfall deficit $\mathrm{N}_{10 \%}(101 \mathrm{~mm})$ was calculated for the C-E region of the country. In June, the lowest rainfall deficit $\mathrm{N}_{50 \%}(20 \mathrm{~mm}), \mathrm{N}_{25 \%}(32 \mathrm{~mm})$ and $\mathrm{N}_{10 \%}(48 \mathrm{~mm})$ values occurred in S-E Poland. In the study reported by Rolbiecki et al. (2018), during June and July, the highest rainfall deficit $(102 \mathrm{~mm})$ during the growing of elderberry plants for three years after planting in the reclaimed areas occurred in the $\mathrm{C}-\mathrm{N}-\mathrm{W}$ region of Poland. In turn, Rolbiecki et al. (2018) had calculated noticeably lower rainfall deficits in the S-W $(72 \mathrm{~mm})$ and C-E $(82 \mathrm{~mm})$ regions of the country. Finally, in S-E Poland they had noted the lowest rainfall deficit $(40 \mathrm{~mm})$.

In the present study, throughout Poland, an evident increase was observed in the elderberry-tree water needs calculated for June and July of the years 1981-2010. Current results confirmed the results published by Łabędzki (2009) and Rolbiecki et al. (2018). The climate changes observed presently, mainly the increase in air temperature, will certainly increase plant water needs and will raise the demand for water required for crop irrigation (Döll, 2002; Łabędzki, 2009). In connection with the presently observed adverse climate changes, activities, such as the development of irrigation techniques, should be undertaken, the aim of which is to mitigate the effects of these changes (Łabędzki, 2009; Kuchar and Iwanski, 2011; Kuchar and Iwanski, 2013; Żarski et al., 2013; Kuchar et al., 2015; Kuchar et al., 2017; Rolbiecki et al., 2017).

The results presented in this paper will be helpful in designing and engineering elderberrytree watering methods. Irrigation techniques are considered as fundamental melioration treatments that ensure development of tree and shrub seedlings in crops and plantings, and in forest nurseries (Rzekanowski and Pierzgalski, 2006; Ptach et al., 2017). Several studies conducted near Bydgoszcz have demonstrated advantageous effects of some melioration treatments (revitalization), e.g. micro-irrigation, on the growth of plants of such species as Pinus sylvestris (Klimek et al., 2008), Betula alba (Klimek et al., 2009), Larix decidua (Klimek et al., 2011), Tilia cordata (Klimek et al., 2013) and Paulownia tomentosa (Ptach et al., 2017). Sambucus nigra L. is not a drought-tolerant species (Byers, 2005; Byers et al., 2014). Elderberry is barely sensitive to the water content in the soil (Tökei et al., 2005), so it grows on almost all types of substrates, but preferably on fertile, medium-dry and moist soils. Elderberry plants are sensitive to particularly dry habitats, such as dunes and gravel soils, where dwarf forms of this species are produced (Dörken, 2011). Based on field experiments, Żakowicz (2010) and also Żakowicz and Hewelke (2012) had confirmed the use of a sprinkler irrigation system for elderberry growing in reclamation plantings in Poland. The favourable effect of the treatments used for elderberry irrigation had also been recorded in Hungary (Tőkei et al., 2005). Correspondingly, in the United States of America, drip irrigation as well as trickle irrigation had been successfully applied to watering elderberry plants (Byers, 2005; Charlebois et al., 2010; Byers et al., 2014).

\section{CONCLUSIONS}

1. In June and July of the considered thirty-year interval (1981-2010), the highest water needs of Sambucus nigra L. grown in reclaimed areas for more than three years were calculated for the central-north-west $(264 \mathrm{~mm})$ and central-east $(262 \mathrm{~mm})$ regions of Poland, while the lowest water needs $(244 \mathrm{~mm})$ were estimated for the south-east region.

2. In June, the highest monthly total of elderberry-tree water needs $(119 \mathrm{~mm})$ was found in south-west Poland, while the lowest water needs $(107 \mathrm{~mm})$ were estimated for the south-east region of the country.

3. In the years 1981-2010, during June and July, an upward time trend of elderberry-tree water needs was observed throughout Poland except the central-north-west region.

4. In June and July, the highest values of rainfall deficit $\mathrm{N}_{50 \%}$ and $\mathrm{N}_{25 \%}$ were estimated for the central-north-west region and the highest rainfall deficit $\mathrm{N}_{10 \%}$ for the central-east region of Poland.

\section{AUTHOR CONTRIBUTIONS}

All authors (S.R., B.J., A.F., W.P., R.R., P.S., W.K.-W., V.G., A.K., K.D.) equally contributed to 
the experimental design, analytical measurements and manuscript writing.

\section{REFERENCES}

BYERS P.L., 2005. Elderberry research and production in Missouri. New York Berry News 4(11), 1-4.

Byers P.L., Thomas A.L., Gold M.A., 2014. Growing and marketing elderberries in Missouri. 2012. University of Missouri Center for Agroforestry in Action Guide, 1-12.

Charlebois D., Byers P.L., Finn C.E., Thomas A.L., 2010. Elderberry: botany, horticulturae, potential. In: Horticulture Reviews. J. Janic (Ed.), WileyBlackwell, New Jersey, USA, 37, 213-280.

DöLL P., 2002. Impact of climate change and variability on irrigation requirements: a global perspective. Clim. Change 54, 269-293.

DöRKen V.M., 2011. Sambucus spp. - Holunder (Caprifoliaceae). Jahrbuch des Bochumer Botanischen Vereins 2, 258-265.

Gramza-MichalowsKa A., Sidor A., 2015. Czarny bez (Sambucus nigra) w dietoterapii chorob cywilizacyjnych. Przemysł Spożywczy 69(1), 38-41.

Kawecki Z., PŁoszaj B., Waźbińska J., 2008. Drzewa i krzewy liściaste. UWM, Olsztyn, Poland.

Klimek A., Rolbiecki S., Rolbiecki R., HilszczańsKa D., MALCZYK P., 2008. Impact of chosen bare root nursery practices in Scots pine seedling quality and soil mites (Acari). Pol. J. Environ. Stud. 17(2), 247255.

Klimek A., Rolbiecki S., Rolbiecki R., Malczyk P., 2009. Impact of chosen bare root nursery practices on white birch seedling quality and soil mites (Acari). Pol. J. Environ. Stud. 18(6), 1013-1020.

Klimek A., Rolbiecki S., Rolbiecki R., HilszczańsKa D., MALCZYK P., 2011. Effects of organic fertilization and mulching under micro-sprinkler irrigation on growth and mycorrhizal colonization of European larch seedlings, and occurrence of soil mites. Pol. J. Environ. Stud. 5(20), 1211-1219.

Klimek A., Rolbiecki S., Rolbiecki R., DŁugosz J., Musiat M., 2013. The use of compost from sewage sludge and forest ectohumus for enrichment of soils in the nursery cultivation of littleleaf linden (Tilia cordata Mill.). Annual Set The Environment Protection 15, 2811-2828.

Kolodziej B., Drożdżal K., 2011. Właściwości przeciwutleniające kwiatów i owoców bzu czarnego pozyskiwanego ze stanu naturalnego. Żywność. Nauka. Technologia. Jakość, 4(77), 36-44.

KUCHAR L., IwAŃSKI S., 2011. Rainfall simulation for the prediction of crop irrigation in future climate. Infrastructure and Ecology of Rural Areas 5, 7-18.

KuCHAR L., IWAŃSKI S., 2013. Rainfall evaluation for crop production until 2050-2060 and selected climate change scenarios for North Central Poland.
Infrastructure and Ecology of Rural Areas 2(I), 187200.

Kuchar L., Iwański S., Diakowska E., Gąsiorek E., 2015. Simulation of hydrothermal conditions for crop production purpose until 2050-2060 and selected climate change scenarios for North Central Poland. Infrastructure and Ecology of Rural Areas II(1), 319-334.

Kuchar L., Iwański S., Diakowska E., GąSiorek E., 2017. Assessment of meteorological drought in 2015 for North Central part of Poland using hydrothermal coefficient (HTC) in the context of climate change. Infrastructure and Ecology of Rural Areas I(2), $257-$ 273.

ŁABĘDZKI L., 2009. Foreseen climate changes and irrigation development in Poland. Infrastructure and Ecology of Rural Areas 3, 7-18.

ŁABĘDZKI L., BĄK B., LisZEwSKA M., 2013. Wpływ przewidywanej zmiany klimatu na zapotrzebowanie ziemniaka późnego na wodę. Infrastructure and Ecology of Rural Areas 2(I), 155-165.

NuRZYŃSKA-WierdaK R., 2016. Właściwości lecznicze i wykorzystanie w fitoterapii niektórych gatunków roślin drzewiastych. Krzewy półkuli północnej. Annales UMCS, Sectio Horticultura XXVI(2), 2746.

Podbielkowski Z., 1989. Słownik roślin użytkowych. PWRiL, Warszawa, Poland.

Ptach W., Łangowski A., Rolbiecki R., Rolbiecki S., Jagosz B., Grybauskiene V., et AL., 2017. The influence of irrigation on the growth of paulownia trees at the first year of cultivation in a light soil. Proc. $8^{\text {th }}$ Int. Sci. Conf. Rural Development, 23-24 November, Aleksandras Stulginskis University, Lithuania, 764-768.

Rolbiecki S., Kokoszewski M., Grybauskiene V., Rolbiecki R., Jagosz B., PTACH W., ET AL., 2017. Effect of expected climate changes on the water needs of forest nursery in the region of central Poland. Proc. $8^{\text {th }}$ Int. Sci. Conf. Rural Development, 23-24 November, Aleksandras Stulginskis University, Lithuania, 786-792.

Rolbiecki S., Rolbiecki R., Jagosz B., Рtach W., Figas A., 2018. Water needs of elderberry (Sambucus nigra L.) in first three years of growing in different regions of Poland. Proc. 17 $7^{\text {th }}$ Int. Sci. Conf. Engineering for Rural Development, 23-25 May, Jelgava, Latvia, 733-737.

Rzekanowski C., Pierzgalski E., 2006. Irrigation of forest nurseries. In: Plant irrigation. S. Karczmarczyk and L. Nowak (Eds), PWRiL, Poznań, Poland, 194197.

Seneta W., 2012. Dendrologia. PWN, Warszawa, Poland.

TöKei L., Dunkel Z., Jung A., 2005. A new method for determining water uptake in elderberry plantation. Phys. Chem. Earth 30, 245-248. 
WoJciechowicZ-ŻYTKo E., JANKOWSKA B., 2016. Sambucus nigra L. as a reservoir of beneficial insects (Diptera, Syrphidae). Folia Hort. 28(2), 209-216.

ŻAKowICz S., 2010. Podstawy technologii nawadniania rekultywowanych składowisk odpadów komunalnych. Rozprawy Naukowe i Monografie SGGW, Warszawa, Poland.

Żakowicz S., Hewelke P., 2012. Technologia nawadniania roślin na rekultywowanych składowiskach odpadów komunalnych. SGGW, Warszawa, Poland.
Żakowicz S., Hewelke P., Gnatowski T., 2009. Podstawy infrastruktury technicznej w przestrzeni produkcyjnej. SGGW, Warszawa, Poland.

ŻARSKI J., DuDEK S., KuŚMIEREK-ToMASZEWSKA R., RolbIECKI R., RolbIECKI S., 2013. Forecasting effects of plants irrigation based on selected meteorological and agricultural drought indices. Annual Set The Environment Protection 15, 2185-2203.

Received April 29, 2019; accepted July 15, 2019 